\title{
ARTI PENTING DIBENTUKNYA \\ PENGADILAN TATA USAHA NEGARA \\ MASRI
}

Email: skbmasri@gmail.com

No BP:2010003600451

UNIVERSITAS EKA SAKTI

\section{A. PENDAHULUAN}

\section{Latar Belakang}

Dasar peradilan dalam UUD 1945 dsapat ditemukan dalam pasal 24 yangmenyebutkan:

(1) Kekuasaan kehakiman dilakukan oleh sebuah Mahkamah Agung dan lain-lain badan kehakiman menurut undang-undang.

(2) Susunan dan kekuasaan badan-badan kehakiman itu diatur dengan undang-undang.

Sebagai pelaksanaan Pasal 24 UUD 1945, dikeluarkanlah Undang-undang Nomor 14 Tahun Tahun 1970 tentang Ketentuan Pokok Kekuasaan Kehakiman. Dalam Pasal 10 ayat (1) disebutkan bahwa kekuasaan kehakiman dilakukan oleh pengadilan dalam lingkungan:
a. Peradilan Umum;
b. Peradilan Agama;
c. Peradilan Militer;
d. Peradilan Tata Usaha Negara.

Indonesia sebagai negara hukum tengah berusaha meningkatkan kesejahteraan bagi seluruh warganya dalam segala bidang. Kesejahteraan itu hanya dapat dicapai dengan melakukan 
aktivitas-aktivitas pembangunan di segala bidang. Dalam melaksanakan pembangunan yang multi kompleks sifatnya tidak dapat dipungkiri bahwa aparatur pemerintah memainkan peranan yang sangat besar. Konsekuensi negatif atas peran pemerintah tersebut adalah munculnya sejumlah penyimpangan-penyimpangan seperti korupsi, penyalahgunaan kewenangan, pelampauan batas kekuasaan, sewenang-wenang, pemborosan dan sebagainya. Penyimpanganpenyimpangan yang dilakukan oleh aparat pemerintahan itu tidak mungkin dibiarkan begitu saja. Disamping itu, juga diperlukan sarana hukum untuk memberikan perlindungan hukum bagi rakyat.

Melihat betapa pentingnya peran Peradilan Tata Usaha negara dalam menciptakan Negara Indonesi ayang adil dan sejahtera, pemakalah tertarik untuk membahas lebih dalam mengenai Peradilan Tata Usaha Negara di Indonesia dengan membuat makalah yang berjudul: “Arti Penting Dibentuknya Pengadilan Tata Usaha Negara”

\section{Rumusan Masalah}

Setelah menyusun latar belakang makalah ini, penulis memiliki beberapa rumusan masalah yang relevan, yaitu:

1. Pengertian Pengadilan Tata usaha Negara

2. Tujuan Pengadilan Tata Uasaha Negara

\section{Tujuan}

Setelah mengetahui rumusan masalah di atas, penulis memiliki beberapa tujuan, di antaranya:

1. Mengetahui Pengertian Pengadilan Tata Usaha Negara

2. Mengetahui Tujuan Pengadilan Tata Uasaha Negara 


\section{B. PEMBAHASAN}

\section{Pengertian Pengadilan Tata Usaha Negara}

Prof. Ir. S. Prajudi Atmosudirdjo, SH memberikan pengertian Peradilan Tata Usaha Negara dalam arti Luas dan sempit.

1)Dalam arti luas

"Peradilan yang menyangkut Pejabat - pejabat dan instansi - instansi Administrasi Negara, baik yang bersifat perkara pidana, perkara perdata, perkara agama, perkara adat dan perkara administrasi negara"

2) Dalam arti sempit

"Peradilan yang menyelesaikan perkara - perkara administrasi negara murnu semata - mata"

\section{Dasar Hukum Pembentukkan Peradilan Tata Usaha Negara (PERATUN)}

a. Keputusan Presiden RI (Keppres) Nomor 2 Tahub 1997 tentang Pembentukan Pengadilan Tata Usaha Negara Banda Aceh, Pekanbaru, Jambi, Bengkulu, Palngkaraya, Palu, Kendari, Yogyakarta, Mataram, dan Dili.

b. Undang - Undang Nomor 5 Tahun 1986, Tentang Peradilan Tata Usaha Negara.

c. Undang - undang Nomor 9 Tahun 2004, Tentang Perubahan atas Undang - undang nomor : 5 Tahun 1986, Tentang Peradilan tata Usaha Negara.

d. Undang Undang Nomor : 5 Tahun 1986, Tentang Peradilan Tata Uasaha Negara. 


\section{Hukum dan Wewenang}

Pengadilan Tata Usaha Negara mempunyai tugas dan wewenang: “ Memeriksa. Memutus dan menyelesaikan sengketa Tata Uasaha Negara, yaitu suatu sengketa yang timbul dalam bidang hokum TUN anatara orang atau badan hokum perdata (anggota masyarakat) dengan Badan atau Pejabat TUN (pemerintah) bail di pusat maupun di daerah sebagai akibat dikeluarkannya suatu keputusan keputusan TUN (beschikking), termasuk sengketa kepegawaian berdasarkan undangan yang berlaku (vide Pasal 50 Jo.Pasal 1 angka 4 Undang unadang Nomor 5 tahun 2004 jincto Undang - undang Nomor 51 Tahun 2009)". Berdasarkan rumusan tersebut maka dapat disimpulkan yang menjadi subjek Peradilan Tata Usaha Negara (PERATUN) adalah seseorang atau badan hokum perdata sebagai penggugat, dan Badan atau pejabat Tata Usaha Negara sebagai tergugat. Sedangkan yang menjadi objek di Peradilan Tata Usaha Negara (PERATUN) adalah Surat Keputusan Tata Usaha Negara (beschikking)

\section{Tujuan Peradilan Tata Usaha Negara}

Fungsi hukum ialah menegakkan kebenaran untuk mencapai keadilan. Keadilan adalah merupakan hal pokok bagi manusia dalam hidup bermasyarakat, maka dibutuhkan adanya Lembaga - lembaga yang bertugas mnyelenggarakan keadilan ini . Keadilan ini dituntutkan untuk semua hubungan masyarakat, hubungan - hubungan yang diadakan oleh manusia dengan manusia lainnya, oleh karena itu berbicara tentang keadilan meliputi segala kehidupan manusia.

Dalam hubungannya dengan manusia lainnya. Keadilan ini erat hubungannya dengan

kebenaran. Karena sesuatu yang tidak benar tidaklah mungkin adil. Sesuatu itu benar menurut 
norma - norma yang berlaku akan tercapailah keadilan itu. Juniarto ,SH mengemukakan ada 4 macam kebenaran untuk mencapai keadilian.

1) Kebenaran dalam menentukan norma - norma hokum yang berlaku agar sesuai dengan rasa kebenaran yang hidup dalam masyarakat.

2) Kebenaran berupa tindakan - tindakan dari setiap anggota masyarakat dalam melakukan hubungan agar sesuai dengan norma -norma hokum yang berlaku.

3) Kebenaran dalam mengetahui fakta - fakta tentang hubungan hubungan yang sesungguhnya terjadi sehingga tidak ada penambhan dan pengurangan maupun penggelapan daripadanya.

4) Kebenaran didalam memberikan penilaian terhadap fakta - faktanya terhadap norma norma hukum yang berlaku

Dengan empat kebenaran yang harus diperhatikan dalam rangka mencapai keadilan. Kepada lembaga - lembaga yang bertugas untuk menetapkan keadilannya atau dengan perkataan lain bertugas memberi kontrol, meminta pertanggungjawaban dan memberikan sanksi - sanksinya, makan tindakan pertama yang harus diperhatikan ialah mencari kebenaran tentang fakta - fakta. Peradilan Tata Usaha Negara adalah salh satu lembaga yang bertugas menyelenggarakankeadlian ini juga harus memperhatikan kebenaran - kebenaran tersebut untuk mencapai keadilan. Demikian pula para anggota yang duduk dalam lembaga ini harus mempunyai keadilan khusus untuk itu dan terutama sekali mempunyai pengetahuan hokum yang cukup luas. Prof.Ir. S. Prajudi Atmosudirjo, SH, mengatakan bahwa tujuan daripada Peradilan Tata Uasaha Negara adalah untuk mengembangkandan memelihara administrasi 
Negara yang tepat menurut hukum (rechmating) atau tepat menurut undang - undang (wetmatig).

Pemakalah sendiri berpendapat bahwa Peradilan Tata Usaha Negara dibentuk untuk menyelesaikan sengketa yang timbul anatara Badan / Pejabat Tata Usaha Negara dengan warga masyarakat oleh akibat pelaksanaan atau penggunaan wewenang pemerintah yang dilakukan oleh Badan / Pejabat Tata Usaha Negara yang menimbulkan benturan kepentingan, perselisihan, atau sengketa dengan warga masyarakat.

\section{Arti penting dibentuknya Hukum Tata Usaha Negara}

Indonesia sebagai Negara hukum, menjun jung tinggi nilai - nilai keadilan, kepastian hukum dan Hak Asasi Manusia (HAM) dan untuk melaksanakna amanat undang - undang pasal 24 ayat (2) UUD 1945 (perubahan) juncto pasal 10 ayat (1) huruf d Undang - undang no 14 tahun 1970 tentang kekuasaan kehakiman yang telah diganti dengan undang - undang no 48 tahun 2009 junto pasal 6 ayat (1) undang - undang nomor 5 tahun1986 tentang Peradilan Tata Usaha Negara sebagaimana telah diubah dengan Undang -undang Nomor 9 tahun 2004 dan perubahan kedua dengan undang - undang nomor 51 tahun 2009, maka dibentuklah Pengadilan Tata Usaha Negara Mataram berdasarkan keputusan Presiden RI (Keppres)Nomor 2 Tahun 1997 tentang Pembentukkan Pengadilan Tata Usaha Negara Banda Aceh, Pakan barau, Jambi, Bengkulu, Palngkaraya, Palu, Kendari, Yogyakarta, MAtaram dan Dili. Tujuan dibentuknya Peradilan Tata Usaha Negara adalah untuk mewujudkan tata kehidupan negra dan bangsa yang sejahtera, aman, tenteram serta tertib yang dapat menjamin kedudukan warga masyarakat dalam hukum dan menjamin terpeliharanya hubungan serasi, seimbang, serta selaras antara aparatur dibidang tata usaha Negara dengan para warga masyarakat. 


\section{PENUTUP}

\section{Kesimpulan}

Pengadilan Tata Usaha Negara adalah Peradilan yang menyangkut pejabat - pejabat dan insatnsi - instansi administrasi Negara, baik yang bersifat perkata perdata, perkara pidana, perkara agama, perkara adat dan perkara administrasi negara.

Peradilan Tata Usaha Negara dibentuk untuk mnyelesaikan sengketa yang timbul antara Badan atau pejabat Tata Usaha Negara dengan warga masyarakat oleh akibat pelaksanaan atau penggunaan wewe.nang pemerintah yang dilakukan oleh Badan atau pejabat Tata Usaha Negara yang menimbulkan benturan kepentingan, perselisihan, atau sengketa dengan warga masyarakat

\section{Saran}

Untuk mengatasi belum optimalnya fungsi PTUN adalah melakukan penyempurnaan peraturan perundang- undangan memasukkan asas pembangunan berkelanjutan dan asas pencegahan dini sebgai pengujian KTUN obyek sengketa dalam penyelesaian sengketa di PTUN segera dibentuk Pengadilan di tiap kabupaten atau kota dan Pengadilan Tinggi TUN di tiap provinsimemberikan sanksi yang dapat dipaksakan kepada para pejabat yang tidak melaksanakan putusan TUN dibentuk pengadilan khusus lingkungan dibawah Peradilan Tata Usaha Negara yang diharapkan mampu memeriksa dan mengadili sengketa secara mendalan dari aspek substansinya.

\section{DAFTAR PUSTAKA}


Darmini Roza dan Laurensius Arliman S, Peran Pemerintah Daerah Di Dalam Melindungi Hak Anak Di Indonesia, Masalah-Masalah Hukum, Volume 47, Nomor 1, 2018. https://doi.org/10.14710/mmh.47.1.2018.10-21

Laurensius Arliman S, Peranan Metodologi Penelitian Hukum di Dalam Perkembangan Ilmu Hukum di Indonesia, Soumatera Law Review, Volume 1, Nomor 1, 201. http://doi.org/10.22216/soumlaw.v1i1.3346.

Laurensius Arliman S, Peran Badan Permusyawaratan Desa di Dalam Pembangunan Desa dan Pengawasan Keuangan Desa, Padjadjaran Journal of Law, Volume 4, Nomor 3, 2017. https://doi.org/10.15408/jch.v4i2.3433.

Laurensius Arliman S, Penanaman Modal Asing Di Sumatera Barat Berdasarkan UndangUndang Nomor 25 Tahun 2007 Tentang Penanaman Modal, Supremasi Hukum, Volume 1, Nomor 1, 2018. http://dx.doi.org/10.36441/hukum.v1i01.102 .

Laurensius Arliman S, Memperkuat Kearifan Lokal Untuk Menangkal Intoleransi Umat Beragama Di Indonesia, Ensiklopedia of Journal, Volume 1, Nomor 1, 2018, https://doi.org/10.33559/eoj.v1i1.18.

Laurensius Arliman S, Perkawinan Antar Negara Di Indonesia Berdasarkan Hukum Perdata Internasional, Kertha Patrika, Volume 39, Nomor 3, 2017 , https://doi.org/10.24843/KP.2017.v39.i03.p03.

Laurensius Arliman S, Partisipasi Masyarakat Di Dalam Pengelolaan Uang Desa PascaUndangUndang Nomor 6 Tahun 2014 Tentang Desa, Jurnal Arena Hukum, Volume 12, Nomor 2, 2019, https://doi.org/10.21776/ub.arenahukum.2019.01202.5.

Laurensius Arliman S, Mewujudkan Penegakan Hukum Yang Baik Di Negara Hukum Indonesia, Dialogica Jurnalica, Volume 11, Nomor 1, 2019, https://doi.org/10.28932/di.v11i1.1831.

Laurensius Arliman S, Mediasi Melalui Pendekatan Mufakat Sebagai Lembaga Alternatif Penyelesaian Sengketa Untuk Mendukung Pembangunan Ekonomi Nasional, UIR Law Review, Volume 2, Nomor 2, 2018, https://doi.org/10.25299/uirlrev.2018.vol2(02).1587

Laurensius Arliman S, Peranan Filsafat Hukum Dalam Perlindungan Hak Anak Yang Berkelanjutan Sebagai Bagian Dari Hak Asasi Manusia, Doctrinal, Volume 1, Nomor 2,2016.

Laurensius Arliman S, Ni Putu Eka Dewi, Protection of Children and Women's Rights in Indonesiathrough International Regulation Ratification, Journal of Innovation, Creativity and Change Volume 15, Nomor 6, 2021.

Laurensius Arliman S, Gagalnya Perlindungan Anak Sebagai Salah Satu Bagian Dari Hak Asasi Manusia Oleh Orang Tua Ditinjau Dari Mazhab Utilitarianisme, Jurnal Yuridis, Volume 3, Nomor 2, 2016, http://dx.doi.org/10.35586/.v3i2.180.

Laurensius Arliman S, Tantangan Pendidikan Kewarganegaraan Pada Revolusi 4.0, Jurnal Ensiklopedia Sosial Review, Volume 2, Nomor 3, 2020.. 